\title{
Substantial Shifts in Supreme Court Health Law Jurisprudence
}

Lawrence O. Gostin

Georgetown University, gostin@law.georgetown.edu

James G. Hodge

Arizona State University Sandra Day O'Connor College of Law, james.hodge.1@asu.edu

This paper can be downloaded free of charge from:

https://scholarship.law.georgetown.edu/facpub/2095

https://ssrn.com/abstract=3248406

Journal of the American Medical Association, Vol. 320, No. 14, 1431.

This open-access article is brought to you by the Georgetown Law Library. Posted with permission of the author. Follow this and additional works at: https://scholarship.law.georgetown.edu/facpub

Part of the Courts Commons, Health Law and Policy Commons, and the Supreme Court of the United States Commons 


\section{Substantial Shifts in Supreme Court Health Law Jurisprudence}

\begin{tabular}{l}
\hline Lawrence O. Gostin, \\
JD \\
O'Neill Institute for \\
National and Global \\
Health Law, \\
Georgetown University \\
Law Center, \\
Washington, DC. \\
\hline James G. Hodge Jr, JD, \\
LLM \\
Center for Public \\
Health Law and Policy, \\
Sandra Day O'Connor \\
College of Law, Arizona \\
State University, \\
Phoenix. \\
\\
$\leftarrow$ \\
Editorial page 1437 \\
$\leftarrow$ \\
Related article \\
page 1489 \\
+ \\
Supplemental \\
content
\end{tabular}

content
On July 9, 2018, President Donald Trump nominated Judge Brett Kavanaugh to replace retiring Supreme Court Justice Anthony Kennedy. Judge Kavanaugh is a respected originalist and textualist, interpreting the law as written, "informed by history, tradition and precedent."1 Given that Justice Kennedy was an important vote in prominent cases affecting health, Judge Kavanaugh's Senate confirmation could shift the balance on consequential health policies (eTable in the Supplement).

\section{Public Health Regulation}

Federal agency regulation remains a bulwark of health, safety, and environmental protection. Agency action is vital in virtually every health policy sphere, including health care access and quality, pharmaceutical approval, food safety, tobacco control, and occupational health. Non-health sector agencies also have major influences on health, including agriculture, transportation, housing, and immigration.

Historically, the Supreme Court has granted agencies considerable leeway to create and enforce regulations under Chevron deference (named for a seminal 1984 decision). ${ }^{2}$ Judge Kavanaugh disfavors broad agency authority. As a jurist, he overrode agency action 75 times. In 2016 he referred to Chevron deference as a "textual

\section{Today, the judiciary is increasingly the arbiter of contested health and social policies.}

invention by courts."3 Striking down administrative regulations creates nearly insurmountable barriers to public health, requiring Congress to expressly support agency action, which is arduous and uncertain in a politically divisive culture.

Judge Kavanaugh has periodically upheld agency action, demonstrating respect for science. Endorsing US Food and Drug Administration rules on drug approvals, Judge Kavanaugh suggested that courts are "illequipped to second-guess scientific judgment." ${ }^{4} \mathrm{He}$ also affirmed US Department of Transportation rules prohibiting e-cigarettes on commercial flights, although deeming it a "close call" under existing tobacco control statutes. ${ }^{5}$

Corresponding

Author: Lawrence O. Gostin, JD,

Georgetown University Law Center, 600 New Jersey Ave NW, McDonough 568, Washington, DC 20001 (gostin@law .georgetown.edu).

\section{Health Care Access and Coverage}

In 2012, the Supreme Court narrowly upheld the Affordable Care Act (ACA) but undercut a key pillar, permitting states to opt out of Medicaid expansion. Judge Kavanaugh had previously argued that the ACA's individual mandate (another key pillar of the ACA) exceeded congressional powers. That became a reality in the 2017 Tax Act, which negated the individual mandate by removing the tax penalty. Judge Kavanaugh has also cast doubt on the ACA's tax credits for health exchange consumers.

The legal future of the ACA is tenuous. Congress has unsuccessfully sought to repeal the ACA 70 times, but numerous judicial challenges are pending. The Justice Department has refused to defend the constitutionality of portions of the ACA. Health care protections that Americans strongly support are at risk, including essential benefits, health exchange subsidies, and a ban on preexisting conditions.

The Centers for Medicare \& Medicaid Services (CMS) recently authorized state waivers for Medicaid work requirements. ${ }^{6}$ Although a lower court overturned CMS's approval of Kentucky's work requirement, the issue is ripe for appellate review. Medicare reimbursement rates are also under litigation. Judge Kavanaugh recently sided with hospitals challenging Medicare reimbursement rates, calling the US Department of Health and Human Services (HHS) reimbursement limits "arbitrary and capricious."7

\section{Reproductive Rights}

If confirmed, Judge Kavanaugh's views on reproductive rights could limit abortion and contraceptive services. President Trump pledged to appoint "pro-life" justices, even those open to overturning Roe $v$ Wade. In his 2006 confirmation hearing, Judge Kavanaugh pledged to follow Roe "faithfully and fully," but his judicial opinions and public statements are inconsistent. In a 2017 speech, Judge Kavanaugh praised former Chief Justice Rehnquist's dissent in Roe for "stemming the general tide of free-wheeling judicial creation of unenumerated rights." The same year, he ordered a delay in accessing abortion services for an undocumented minor in federal custody. When the court later vacated the order, Judge Kavanaugh criticized it for creating a "radical new right to immediate abortion on demand." In 2015, he unsuccessfully argued that the ACA's contraception coverage requirement violated religious freedoms, calling HHS' procedural requirements "overly restrictive."

\section{Second Amendment}

Judge Kavanaugh has robustly defended the Second Amendment. Dissenting from his court's upholding of a municipal ban on semiautomatic rifles and firearm licensing, he explicitly rejected a Second Amendment "balancing" test, favoring gun rights over public safety. Current Supreme Court jurisprudence allows ample room for common-sense gun violence prevention laws. Yet its prior cases focus primarily on firearms ownership for 
home protection. The Court will have to decide if gun rights apply equally in public places, such as "open carry" laws.

Congress has also enacted pro-gun legislation, preempting lawsuits against firearms manufacturers and dealers who negligently sell inherently dangerous weapons, which are then used to commit violent crimes. Parents of children murdered at Sandy Hook Elementary School (and others) are proposing novel theories to judicially challenge manufacture and sale of unusually dangerous weapons, which could be reviewed by the Supreme Court.

\section{Consumer Protection Litigation}

Over many decades, courts have initiated landmark public health achievements, such as the seminal tobacco cases. Judge Kavanaugh has expressed a constricted view of consumer protection litigation. He summarily rejected class action litigation seeking lactose intolerance warning labels on dairy products, concluding: "Tort law does not provide protection from the obvious or 'widely known' risks of consuming a particular food." ${ }^{8}$ His pro-business opinions could affect ongoing public health litigation focusing on opioids, nutrition labeling, and health warnings.

\section{Environmental Protection}

The USEnvironmental Protection Agency (EPA) has withdrawn or limited 70 Obama-era regulations, with many EPA actions now embroiled in litigation. Judge Kavanaugh has often ruled against environmental rules. He invalidated EPA regulations limiting emissions affecting upwind states. He blocked lawsuits seeking stricter carbon monoxide regulation. He invalidated EPA hydrofluorocarbon standards. With President Trump's withdrawal from the Paris Agreement and reversal of climate change regulations, the Court may have to decide whether a new administration can lawfully overturn existing rules without due deliberation and a persuasive scientific record.

Medical Marijuana

In 2018, Attorney General Jeff Sessions reversed settled legal doctrine, declaring his intent to enforce a federal ban on marijuana use despite 30 jurisdictions legalizing marijuana for medical use. California pledged to pursue every legal and political option to protect state rights. Can federal agents prosecute marijuana producers or distributors complying with state law? Prior opinions suggest Judge Kavanaugh may side with the states, refusing to allow the Justice Department to strictly enforce federal criminal law in jurisdictions where medical marijuana is lawful.

\section{Antidiscrimination}

Fair and impartial administration of health services and benefits is vital for disadvantaged populations. Judge Kavanaugh often favors private industry in antidiscrimination lawsuits. He rejected Americans With Disabilities Act lawsuits alleging workplace discrimination. He also dissented when his court ruled in favor of workers assisting at-risk youth from having to undergo mandatory drug tests.

The Supreme Court has been narrowly divided on LGBTQ rights. Justice Kennedy wrote an historic opinion upholding samesex marriage, calling it "a fundamental right inherent in the liberty of the person." This past term, however, Justice Kennedy sided with a narrow Court majority denying relief to a gay couple turned away from a Colorado bakery based on a religious objection to gay marriage. As cases come before the Court pitting religious freedom against equal rights, Judge Kavanaugh's views could be decisive. Key issues on the horizon include spousal benefits in same-sex marriages and conscientious objections to reproductive services.

\section{Changing Health Norms}

Health policy used to largely be the province of Congress and regulatory agencies acting on scientific evidence. Today, the judiciary is increasingly the arbiter of contested health and social policies. Battles over judicial nominations are supplanting legislative and regulatory deliberation. At stake are vital issues for public health, safety, and the environment. More than ever, policy makers and judges must rigorously examine scientific evidence and respect ethical values of justice and equity.

\section{ARTICLE INFORMATION}

Published Online: September 6, 2018. doi:10.1001/jama.2018.12331

Conflict of Interest Disclosures: The authors have completed and submitted the ICMJE Form for Disclosure of Potential Conflicts of Interest and none were reported.

REFERENCES

1. Weiss DC. Meet Brett Kavanaugh, Trump's nominee for the Supreme Court. July 10, 2018. http://www.abajournal.com/news/article/meet _brett_kavanaugh_trumps_nominee_for_the _supreme_court. Accessed July 31, 2018.

2. Chevron USA Inc v NRDC, 467 US 837 (1984).

3. Kavanaugh BM. Fixing statutory interpretation. Har Law Rev. 2016;129(8):2118-2163.

4. Cytori Therapeutics v FDA, 715 F3d 922 (DC Cir 2013).

5. Competitive Enterprise Institute v DOT, $863 \mathrm{F3C}$ 911 (DC Cir 2017).
6. Schmidt $\mathrm{H}$, Hoffman AK. The ethics of Medicaid's work requirements and other personal responsibility policies. JAMA. 2018;319(22):22652266. doi:10.1001/jama.2018.3384

7. St Francis Medical Center v Azar, 894 F3d 290 (DC Cir 2018).

8. Mills v Giant of Maryland, 508 F3d 11 (DC Cir 2007). 